\title{
Micronutrient deficiencies in African soils and the human nutritional nexus: opportunities with staple crops
}

\author{
J. Kihara $(\mathbb{D} \cdot$ P. Bolo $\cdot$ M. Kinyua $\cdot$ J. Rurinda $\cdot$ K. Piikki
}

Received: 23 July 2019/ Accepted: 18 December 2019/Published online: 4 January 2020

(C) The Author(s) 2020

\begin{abstract}
A synthesis of available agronomic datasets and peer-reviewed scientific literature was conducted to: (1) assess the status of micronutrients in sub-Saharan Africa (SSA) arable soils, (2) improve the understanding of the relations between soil quality/management and crop nutritional quality and (3) evaluate the potential profitability of application of secondary and micronutrients to key food crops in SSA, namely maize (Zea mays L.), beans (Phaseolus spp. and Vicia faba L.), wheat (Triticum aestivum L.) and rice (Oryza sativa L.). We found that there is evidence of widespread but varying micronutrient deficiencies in SSA arable soils and that simultaneous deficiencies of multiple elements (co-occurrence) are prevalent. Zinc $(\mathrm{Zn})$ predominates the list of micronutrients that are deficient in SSA arable soils. Boron (B), iron $(\mathrm{Fe})$, molybdenum $(\mathrm{Mo})$ and copper $(\mathrm{Cu})$ deficiencies are also common. Micronutrient fertilization/ agronomic biofortification increases micronutrient
\end{abstract}

J. Kihara $(\bowtie) \cdot$ P. Bolo $\cdot$ M. Kinyua $\cdot$ K. Piikki International Center for Tropical Agriculture (CIAT), Nairobi, Kenya

e-mail: j.kihara@cgiar.org

J. Rurinda

International Plant Nutrition Institute (IPNI), Nairobi, Kenya

K. Piikki

Swedish University of Agricultural Sciences (SLU),

Skara, Uppsala, Sweden concentrations in edible plant organs, and it was profitable to apply fertilizers containing micronutrient elements in $60-80 \%$ of the cases. However, both the plant nutritional quality and profit had large variations. Possible causes of this variation may be differences in crop species and cultivars, fertilizer type and application methods, climate and initial soil conditions, and soil chemistry effects on nutrient availability for crop uptake. Therefore, micronutrient use efficiency can be improved by adapting the rates and types of fertilizers to site-specific soil and management conditions. To make region-wide nutritional changes using agronomic biofortification, major policy interventions are needed.

Keywords Micronutrients - Fertilization - SubSaharan Africa · Human nutrition · Soil fertility management $\cdot$ Biofortification $\cdot$ Profitability

\section{Introduction}

Soil nutrients status and management not only determine crop productivity but nutrients concentration in plant parts consumed as food and feed. Consequently, soil nutrients status has great implications on human health. At global scale, about one-third of arable soils are deficient in micronutrients, particularly in zinc (Zn) (Cakmak et al. 2017), and this eventually affects 
human nutrition. Approximately $2-3$ billion people worldwide are suffering from micronutrient deficiencies, especially in developing countries where these affect at least half of the population (Goudia and Hash 2015). The problem of micronutrient deficiencies in soils (often involving $2-5$ micronutrients at a time) is particularly widespread in SSA (Berkhout et al. 2017; Hengl et al. 2017). This is mainly a result of decades of soil degradation and low and unbalanced application of fertilizers mostly of nitrogen $(\mathrm{N})$, phosphorous (P) and potassium (K). The importance of micronutrients in crop productivity was recently demonstrated (Kihara et al. 2017), but a huge gap remains in understanding their links to nutrition.

The nutritional quality of crop produce influences human nutrition either directly or indirectly (Dimkpa and Bindraban 2016). Consumption of food crops deficient in micronutrients (due partly to lack of adequate micronutrients in the soil, Manzeke et al. 2019) could occasion deficiency of such micronutrients in humans, often referred to as "hidden hunger" (Joy et al. 2015). Hidden hunger, the challenge widely documented in the 2014 Global Hunger Index report (von Grebmer et al. 2014), is largely a problem of inadequate intake of micronutrients. The severity of this in SSA has been demonstrated through ratings of the global hunger index, which is based on undernourishment, child underweight and child mortality. With the exception of Ghana and Gabon, most countries in SSA have global hunger index ratings of between serious and extremely alarming (von Grebmer et al. 2014). Agronomic biofortification through micronutrient application to crops (in soil or foliar) has the potential to ameliorate micronutrient deficiencies and improve crop productivity and nutritional quality of produce.

Food consumption patterns in Africa, especially among resource-constrained small-holder farmers, are dominated by staple cereals including maize and rice. However, micronutrients (especially $\mathrm{Zn}$ ) deficiency in humans is mostly common in areas where cereals grown in micronutrient-deficient soils dominate the diets (Zou et al. 2012; Dimkpa and Bindraban 2016). Globally, $\mathrm{Zn}$ and iron $(\mathrm{Fe})$ predominate the list of micronutrients commonly limiting in human diets (White and Broadley 2009; Stein 2010). For instance, although a concentration ranging between 40 and $60 \mathrm{mg} \mathrm{Zn} \mathrm{kg}{ }^{-1}$ in maize grain is recommended for human consumption (Pfeiffer and McClafferty 2007), less than $35 \mathrm{mg} \mathrm{Zn} \mathrm{kg}^{-1}$ was contained in maize grain produced in the $\mathrm{Zn}$-deficient soils in Zimbabwe (Manzeke et al. 2012, 2019).

The extent to which agronomic management practices enhance changes in crop nutritional quality, due especially to micronutrients, is hardly studied in SSA. For a long time, many studies in SSA have been focusing on the impact of macronutrients on crop productivity (e.g., Kihara et al. 2017). Of the few studies that have assessed the impact of $\mathrm{Zn}$ fertilizers on $\mathrm{Zn}$ concentrations in grains of major food crops, only two have focused on Africa, (i.e., a study conducted in Zambia by Zou et al. (2012) and in Zimbabwe by Manzeke et al. (2014). Nevertheless, interest has now been growing and only a few months ago a comprehensive study on mapping soil nutrient status of $\mathrm{Zn}$ and $\mathrm{Fe}$ across 350 locations in two agroecological regions of Zimbabwe was published (Manzeke et al. 2019). There are also studies that have now included crop quality data such as the recent soil nutrient diagnostic trials of Africa Soil Information Service (AfSIS), the Taking Maize Agronomy to Scale in Africa (TAMASA) and the Optimizing Fertilizer Recommendations in Africa (OFRA) projects) that provide an opportunity for wide-scale assessments to complement the scanty data in peerreviewed publications.

Evidence showing that agricultural interventions are profitable is important to derive their adoption by partners and farmers. While the assessment of profitability of agronomic interventions has been undertaken for macronutrients (e.g., Kihara et al. 2016), no information on profitability of secondary and micronutrient fertilization on yields and nutritional quality of crops is available for SSA. Recently, positive changes in crop yields have, however, been observed when micronutrient fertilizer was applied in Africa (Kihara et al. 2017), and this provides a basis for a comprehensive assessment of the profitability of micronutrient fertilization. Elsewhere, for example in India, Dar (2004) showed that application of boron (B) and sulfur (S) was profitable for both soybean and wheat. The objectives of this study were:

(1) To assess the extent of micronutrient deficiencies in SSA arable soils based on soil analysis, crop grain and quality response datasets,

(2) To improve the understanding of the relations between soil quality/management and food 
crops' nutritional quality and thereby provide the potential estimates of nutritional benefits of agronomic biofortification, by application of micronutrient fertilizers,

(3) To evaluate the profitability of application of secondary and micronutrients in production of key food crops in SSA.

This study focuses on the SSA region where malnutrition and hidden hunger are key problems, and the extent of soil micronutrient deficiencies is extensive.

\section{Methods}

Extent of micronutrient deficiency in SSA

We evaluated the extent of micronutrient deficiencies in arable soils of SSA based on literature review focusing on data and reports of: (1) soil test-based assessments, for example, by Hengl et al. (2017) and Berkhout et al. (2017), (2) crop grain yield responses to nutrients, for example, by Kihara et al. (2017) and (3) micronutrient element concentrations in plant parts (grain, stover and leaves of the different crops).

Soil and crop data acquisition

The agronomic data used in this study were derived from multiple sources. First, we used a database on assessment of crop response to secondary and micronutrients in SSA by Kihara et al. (2017). This database was refreshed by additional literature searches. Additional data published by Manzeke et al. (2019) and by Wortmann et al. (2019a) were then included. To extend the dataset, unpublished plant analyses data containing micronutrient concentrations (in grain, stover and ear leaves) and grain yields were obtained from different sources (Table 1; Fig. 1). This included AfSIS data from Malawi and Kenya, Africa RISING data from Ethiopia, TAMASA data from Nigeria (Shehu et al. 2018), data obtained from specific researchers, e.g., omissions trials data conducted in Nigeria and Togo (Nziguheba et al. 2009). All these datasets contain plant nutrient concentrations such as calcium $(\mathrm{Ca})$, magnesium $(\mathrm{Mg})$, S, manganese $(\mathrm{Mn}), \mathrm{B}$, molybdenum (Mo), Fe and copper $(\mathrm{Cu})$, besides $\mathrm{Zn}$, which is the most commonly reported plant micronutrient in SSA.
Price data for different micronutrient fertilizers were obtained from both local and international fertilizer suppliers. Unlike macronutrients, there was no online site or portal offering micronutrient fertilizer prices, so personal contacts to the major fertilizer suppliers were made to acquire up to date prices (Table 2). Since the majority of the price information for the inputs (micronutrient fertilizers) and outputs (maize yields) were mostly from sources in Kenya, there might be slight variations in prices across SSA.

In calculations of the micronutrient element price, the amount (percentage) of the micronutrient element in the different fertilizer products was first calculated based on the molecular masses of the constituents in the compound fertilizer. The price of the compound fertilizer product was divided by the total amount (percentage) of the target micronutrient element contained to obtain price in kilogram of the micronutrient element. The total price of the target micronutrient was finally arrived at by multiplying the resultant cost per kilogram with quantity of secondary or micronutrient element applied per hectare. Where the treatment involved two or more of the secondary and micronutrients, i.e., "combined," the total cost for the different fertilizer products used was considered.

Variable sources of secondary and micronutrient fertilizers were used in the compiled studies. These sources included: zinc sulfate, zinc sulfate monohydrate, zinc chelate, zinc oxide, zinc carbonate and zinc chloride for $\mathrm{Zn}$; sodium borate, boron chloride and sodium pentaborate for B; sodium molybdate for Mo; copper sulfate and copper oxide for $\mathrm{Cu}$; ammonium sulfate, potassium sulfate, sodium sulfate, ammonium sulfate nitrate, single superphosphate and gypsum for $\mathrm{S}$; iron sulfate for $\mathrm{Fe}$ and sodium selenite for Se. Some of these fertilizer sources are used for their availability on the market, but not because of being the cheapest sources of the required secondary and micronutrients. Unless in chelated form with high nutrient concentration of the products, the cheapest sources of the nutrients were used in the present analyses. Our estimates are conservative as they assume that the fertilizer product is bought solely for supplying a particular secondary or micronutrient of interest. For S from ammonium sulfate (still the cheapest way to acquire sulfur), for example, the price would reduce from US\$ $2.3 \mathrm{~kg}^{-1}$ (Table 2) to about US\$1.8 kg-1 if the known price of the contained nitrogen is subtracted. 
Table 1 Summary of plant micronutrient concentrations data obtained from different sources in sub-Saharan Africa, for the crops, maize (Zea mays L.), wheat (Triticum aestivum L.), rice
(Oryza sativa L.), cowpea (Vigna unguiculata L.), pearl millet (Pennisetum glaucum), finger millet (Eleusine coracana Gaertn.) and sorghum (Sorghum bicolor L.)

\begin{tabular}{|c|c|c|c|c|c|}
\hline Country & Crops & $\begin{array}{l}\text { Crop } \\
\text { parts }\end{array}$ & Micronutrients & Count & Data sources \\
\hline Benin & Maize & Leaves & $\mathrm{Zn}$ & 100 & Diagnostic trials \\
\hline Ethiopia & Wheat & Grain & $\mathrm{S}$ & 24 & Habtegebriel and Singh (2009) \\
\hline Ghana & Cowpea, maize & Shoots & $\mathrm{Zn}$ & 84 & Wortmann et al. (2019a, b) \\
\hline Kenya & Maize & Leaves & $\mathrm{Zn}$ & 1014 & AFSIS \\
\hline Malawi & Cowpea, maize & $\begin{array}{l}\text { Grain, } \\
\text { leaves }\end{array}$ & $\begin{array}{l}\mathrm{Zn}, \mathrm{Se}, \mathrm{Cu}, \\
\mathrm{Mn}, \mathrm{S},\end{array}$ & 2570 & $\begin{array}{l}\text { Chilimba et al. (2012/2014), Wortmann et al. } \\
(2019 a, \text { b), AFSIS }\end{array}$ \\
\hline Mali & Maize, pearl millet & Shoots & $\mathrm{Zn}$ & 333 & Wortmann et al. (2019a, b) \\
\hline Niger & $\begin{array}{l}\text { Cowpea, maize, pearl } \\
\text { millet, sorghum }\end{array}$ & Shoots & $\mathrm{Zn}$ & 1232 & Wortmann et al. (2019a, b) \\
\hline Nigeria & Maize, sorghum & $\begin{array}{l}\text { Shoots, } \\
\text { leaves }\end{array}$ & $\mathrm{Zn}, \mathrm{Mn}, \mathrm{S}, \mathrm{B}$ & 6246 & $\begin{array}{l}\text { AFSIS, TAMASA, Nziguheba et al. (2009), } \\
\text { Wortmann et al. (2019a, b) }\end{array}$ \\
\hline Rwanda & Maize, sorghum & Shoots & $\mathrm{Zn}$ & 28 & Wortmann et al. (2019a, b) \\
\hline Tanzania & Cowpea, maize, sorghum & $\begin{array}{l}\text { Grains, } \\
\text { shoots }\end{array}$ & $\mathrm{Zn}, \mathrm{Cu}$ & 394 & Wortmann et al. (2019a, b), Lisuma et al. (2006) \\
\hline Togo & Maize & Leaves & $\mathrm{Zn}, \mathrm{Mn}, \mathrm{S}, \mathrm{B}$ & 1115 & Diagnostic trials \\
\hline Uganda & Finger millet & Shoots & $\mathrm{Zn}$ & 665 & Wortmann et al. (2019a, b) \\
\hline Zambia & Maize, wheat & $\begin{array}{l}\text { Grains, } \\
\text { shoots }\end{array}$ & $\mathrm{Zn}$ & 117 & $\begin{array}{l}\text { Zou et al. (2012); Ram et al. (2015), Wortmann } \\
\text { et al. (2019a, b) }\end{array}$ \\
\hline Zimbabwe & $\begin{array}{l}\text { Cowpea, finger millet, } \\
\text { maize, sorghum }\end{array}$ & Grain & $\mathrm{Zn}$ & 706 & Manzeke et al. (2019) \\
\hline
\end{tabular}

AfSIS = Africa Soil Information Service; TAMASA = Taking Maize Agronomy to Scale in Africa

Cost of transport of micronutrients was not taken into account as this is easily absorbed in transport costs of macronutrients. (Farmers normally buy micronutrients together with macronutrients.) However, when micronutrient products are not available, farmers would travel beyond common distances of between 2 and $5 \mathrm{~km}$ to agro-dealer outlets (McCall 1985; Misiko 2012). Our analyses assume a scenario where the products are available locally.

Net benefits were calculated as the difference between additional gross income and costs of the secondary and micronutrient fertilizers used. Gross income was obtained by multiplying micronutrient yield response, calculated by subtracting the control yield from the micronutrient yield, with the output prices. These agricultural outputs (yield) prices were averaged for 5 years ranging from January 2014 to January 2019 obtained from FAO (http://www.fao. org/giews/food-prices accessed on January 29, 2019). All the prices were for countries in Eastern Africa, i.e., rice (Oryza spp.) for Tanzania, wheat (Triticum aestivum L.) and sorghum (Sorghum bicolor L.) for Ethiopia and maize (Zea mays L.) for Kenya, representing the dominant crops in each of these countries. Soybean (Glycine max L.) and cowpea (Vigna unguiculata L.) prices were not available in the FAO portal and were obtained from local outlets in Kenya, e.g., National Farmers Information System (nafis.go.ke) and kilimo.go.ke.

Data analysis

\section{Soil and plant micronutrient analysis}

Boxplots showing distributions of concentrations of specific nutrients in harvested plant parts for different crops were generated using $\mathrm{R}$ statistical program. The boxplots show the median of the data, the interquartile range represented by the middle "box" and distributions of data beyond the lower and upper quartiles. To 
Fig. 1 Data entries (n) obtained and used in the analysis of quality effects and profitability of micronutrients in subSaharan Africa covering seven crops: maize (Zea mays L.), wheat (Triticum aestivum L.), rice (Oryza sativa L.), cowpea (Vigna unguiculata L.), pearl millet (Pennisetum glaucum), finger millet (Eleusine coracana Gaertn.) and sorghum (Sorghum bicolor L.) and selected micronutrient elements (not all combinations present). $*=178$ of these were also used for analysis of effects. Background map: Food and Agriculture Organization of the United Nations. FAO GEONETWORK. Global Administrative Unit Layers (GAUL) (GeoLayer).

(Latest update: 04 Jun 2015)

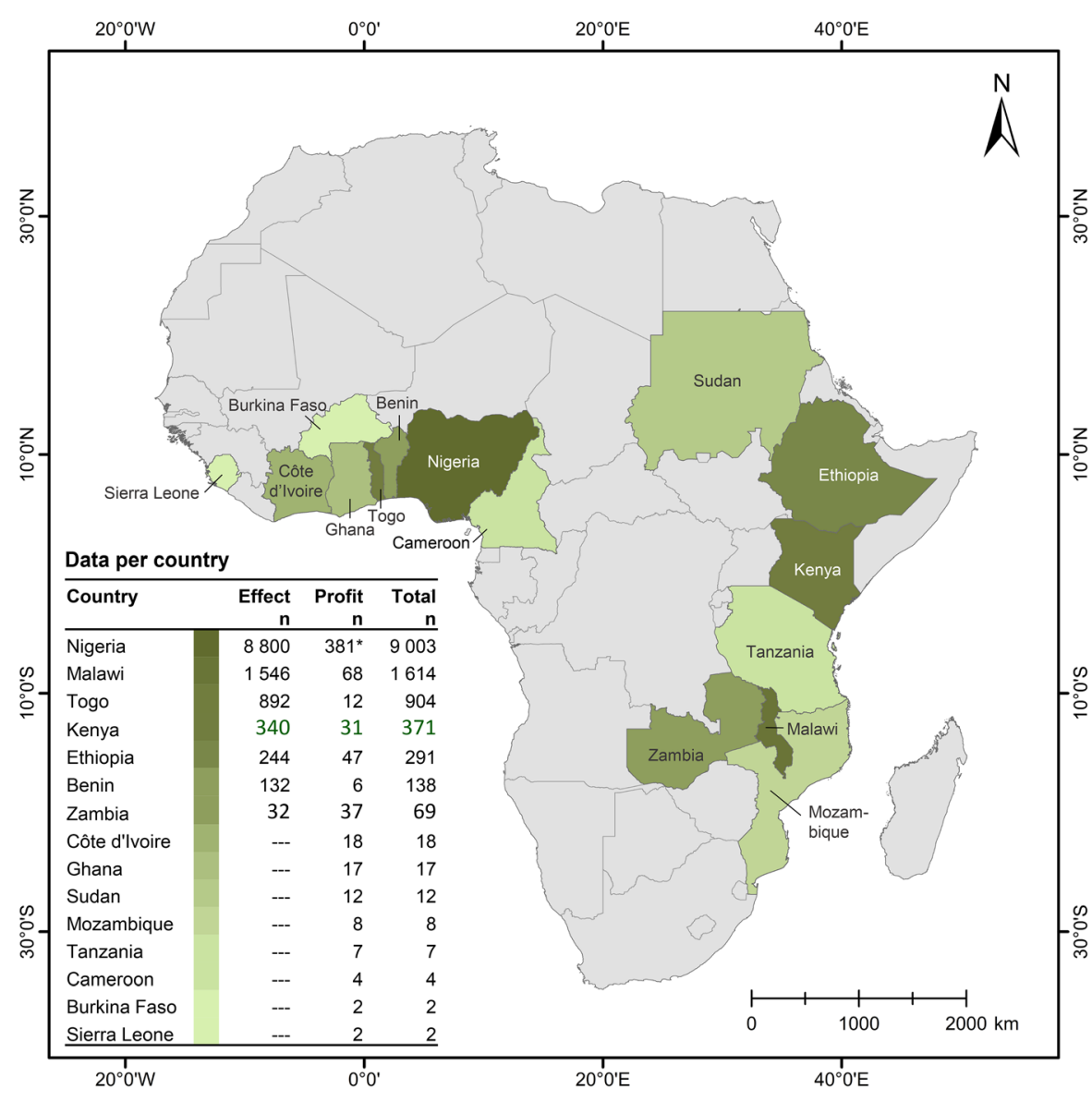

Table 2 Prices (as of May, 2019) and sources of micronutrients used in the study

\begin{tabular}{lllll}
\hline Fertilizer compound & Target element & Proportion element $(\%)$ & Price of element (US\$ kg $\left.{ }^{-1}\right)$ & Source \\
\hline Zinc chelate (EDTA) & $\mathrm{Zn}$ & 15.03 & 16.2 & Global green planet \\
Zinc sulfate & $\mathrm{Zn}$ & 40.5 & 4.3 & Ocean agriculture \\
Ammonium sulfate & $\mathrm{S}$ & 24.27 & 2.3 & Ocean agriculture \\
Iron sulfate & $\mathrm{Fe}$ & 36.76 & 6.0 & Skylab Nairobi \\
Sodium pentaborate & $\mathrm{B}$ & 3.66 & 6.2 & Hemal impex (Indiamart.com) \\
Copper sulfate & $\mathrm{Cu}$ & 39.8 & 14.6 & Ocean agriculture \\
\hline
\end{tabular}

show critical thresholds as reference in interpreting the nutrient concentrations, broken lines indicating minimum critical values were added to the plots.

The means of maize ear leaf $\mathrm{Zn}, \mathrm{Mn}, \mathrm{B}$ and $\mathrm{S}$ concentrations for selected treatments (control [no input], NPK and NPK plus secondary and micronutrients) were obtained from the raw data. For this, bootstrap confidence limits were obtained using boot $\mathrm{R}$ package with 100 replications.

For $\mathrm{Zn}$, co-located data for both plant and soil tests were available allowing us to show the overall distributions of the concentrations, but also how these are influenced by the available levels in the soils. For this, scatter plots of plant $\mathrm{Zn}$ concentrations (in grains 
and leaves) for different crops against soil test $\mathrm{Zn}$ concentrations were undertaken in Microsoft Excel.

\section{Economic analysis of micronutrients use}

Profitability analysis of micronutrient application using the available experimental data in SSA was undertaken with caution. Agronomic trials of crop responses to micronutrients, especially where factorial designs are used, often apply exclusion principles that demand a fertilizer product that may come at a very high price just to eliminate another nutrient of interest to a research project. For example, to avoid nitrogen in $-\mathrm{N}+\mathrm{S}$ treatments, Habtegebrial and Singh (2009) used potassium sulfate that is more expensive than ammonium sulfate used in the $+\mathrm{N}+\mathrm{S}$ treatments. The source of micronutrient was not provided in Chaguala et al. (2011) and was assumed to be the most commonly used, being ammonium sulfate for $\mathrm{S}$ (the treatment needed $\mathrm{N}$ as well) and zinc sulfate for $\mathrm{Zn}$. The calculated micronutrient prices could be slightly overestimated, since only the target micronutrient was costed from the compound fertilizer.

Cumulative frequency distributions of net benefits for the individual crops and nutrient applications were derived when the number of observations was at least 30. The distributions were plotted in $\mathrm{R}$ statistics software with the cumulative probability represented by a graph of the cumulative distribution function. This displays the benefits, sorted in increasing order, and their whole range is shown in the $\mathrm{x}$-axis.

\section{Results and discussion}

Extent of micronutrient deficiencies in subSaharan Africa

The available micronutrient contents in arable soils for much of SSA are below critical thresholds (Toenniessen et al. 2008). Previous review on micronutrient problems in west Africa pointed to boron, zinc and molybdenum deficiencies as the most prevalent (Abe et al. 2010; Buri et al. 2000), while the highest deficiencies for boron and copper occur in the subhumid zones (Hengl et al. 2017). Based on their review, Kihara et al. (2017) pointed out major hotspots for widespread deficiencies in micronutrients in Ivory Coast, Nigeria, Togo, Democratic Republic of Congo,
Kenya, Sudan, Ethiopia, Ghana, Malawi, Sierra Leone, Tanzania, Zambia as well as Burkina Faso. Other researchers have reported widespread deficiencies, e.g., for Zn, S and B in Ethiopia (Vanlauwe et al. 2015) and S in Malawi (Chilimba and Chirwa 2000). Although deficiencies of secondary and micronutrients are associated with continued mining by crops because of non-application of these nutrients in production, there is no long-term data in SSA to show their trends in the soil.

In some regions of SSA, multiple deficiencies of up to five micronutrients are prevalent (Berkhout et al. 2017). The most affected regions with the co-occurrence of micronutrient deficiencies (with up to five nutrients) are in the northern edge of the Sahel of West Africa, areas around the Congo basin, Eastern Africa, and Southern Africa (Berkhout et al. 2017). Due to agronomic associations, the deficiency of even one micronutrient can affect crop productivity and nutritional quality.

Micronutrients and crop nutritional quality

The SSA region's human nutritional requirements are fast soaring up, with its population estimated to hit 2.5 billion by the year 2050 (UN, DESA 2015). When not taken in adequate quantities, the essential micronutrients impact productivity and human health in a wide range of ways (Welch and Graham 2012).

\section{Selenium (Se) in harvest grains}

Crop nutritional quality was found to be improved through micronutrient applications. Selenium (Se), applied either as selenate or as selenite, is not required for plant growth, but it is a critical nutrient for animals and human beings. Topdressing pastures with $\mathrm{Se}$ at a rate of $10 \mathrm{~g} \mathrm{ha}^{-1}$ prevents Se deficiency in livestock (Curtin et al. 2006). In Malawi, application of one gram of Se per hectare (from either $\mathrm{Na}_{2} \mathrm{SeO}_{4(\mathrm{aq})}$, $\mathrm{NPK}+\mathrm{Se}$ or $\mathrm{CAN}+\mathrm{Se}$ ) increased maize stover quality and grain Se concentration by $15-21 \mu \mathrm{g} \mathrm{Se}$ $\mathrm{kg}^{-1}$ (Fig. 2; Chilimba et al. 2012).

In a follow-up study, application of $10 \mathrm{~g} \mathrm{Se} \mathrm{ha}^{-1}$ increased selenium grain concentration by eightfold (from 13 to $113 \mu \mathrm{g} \mathrm{Se} \mathrm{kg}^{-1}$ grain) in maize, ninefold in groundnut (from 43 to $415 \mu \mathrm{g} \mathrm{Se} \mathrm{kg} \mathrm{gg}^{-1}$ grain) and 18 -fold in soybean (from 45 to $813 \mu \mathrm{g} \mathrm{Se} \mathrm{kg}{ }^{-1}$ grain; Chilimba et al. 2014). Such increases are also 
observed elsewhere; in Australia, Se application (ranging from 4 to $120 \mathrm{~g} \mathrm{Se} \mathrm{ha}^{-1}$ ), either as soil or as foliar application, resulted in 133-fold and 20-fold increases in wheat grain Se concentrations, respectively (Lyons et al. 2003). Through such agronomic biofortification with $\mathrm{Se}$, daily per capita maize-based Se intake can be increased to contribute a greater proportion of the recommended daily per capita $\mathrm{Se}$ intake of 50-70 $\mu \mathrm{g}$ (Chilimba et al. 2011).

From the present analysis, applying 1-5 $\mathrm{g} \mathrm{Se} \mathrm{ha}^{-1}$ is inadequate to attain the minimum acceptable range of Se concentrations in grains $\left(0.1 \mathrm{mg} \mathrm{Se} \mathrm{kg}^{-1}\right.$ (Curtin et al. 2006); Fig. 2). Applying at least $6 \mathrm{~g} \mathrm{ha}^{-1} \mathrm{Se}$ results in selenium concentrations in grains above this minimum threshold. Even application of 25-100 $\mathrm{g} \mathrm{ha}^{-1}$ Se still results in concentrations below

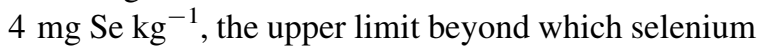
toxicity can result in humans and livestock through food and feed (Underwood and Suttle 1999; Underwood 1977). In general, Se application has a positive effect on the nutritional value, and there is a very wide

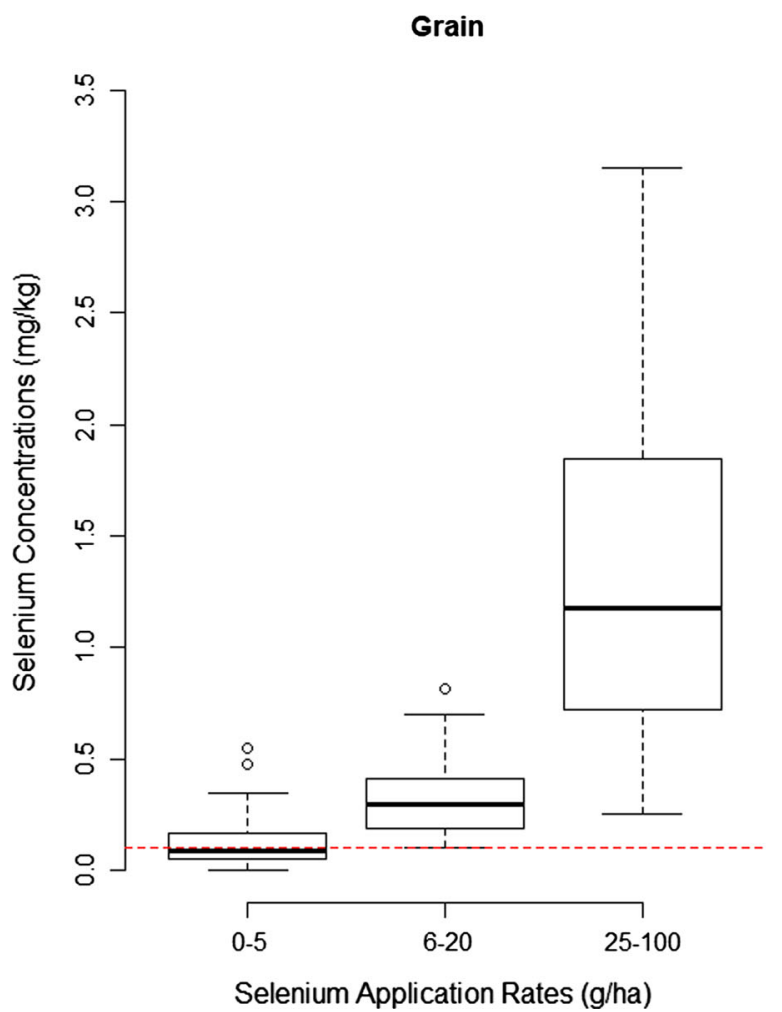

Fig. 2 Selenium concentrations in maize grain and stover under different ranges of Se application rates in maize (Zea mays L.). The mid-line is the median. The box indicates interquartile variation in crop response to its application, indicating the need for site-specific application rates.

The normal range of total Se in soils is given as 0.01-2.0 $\mathrm{mg} \mathrm{kg}^{-1}$ (Saha et al. 2017). The available data for soil Se in Malawi, despite varying widely (over 12-fold), are still low, range of $0.05-0.62 \mathrm{mg} \mathrm{Se} \mathrm{kg}^{-1}$ for total Se and 0.001 and $0.016 \mathrm{mg} \mathrm{Se} \mathrm{kg}{ }^{-1}$ for $\mathrm{KH}_{2} \mathrm{PO}_{4}$-extractable soil $\mathrm{Se}$ (Chilimba et al. 2011). Depending on the total selenium levels in the soil to meet the human Se nutrition demands, soils have been categorized as deficient $\left(<0.125 \mathrm{mg} \quad \mathrm{Se} \quad \mathrm{kg}^{-1}\right), \quad$ marginal (0.125-0.175 mg Se $\left.\mathrm{kg}^{-1}\right)$, moderate to high (0.175-3 $\mathrm{mg} \mathrm{Se} \mathrm{kg}^{-1}$ ) and excessive ( $>3 \mathrm{mg} \mathrm{Se}$ $\mathrm{kg}^{-1}$; Saha et al. 2017). Soils containing more than $5 \mathrm{mg} \mathrm{Se} \mathrm{kg}{ }^{-1}$ produce vegetation with $\mathrm{Se}$ in toxic levels for animal consumption. In Malawi, Chilimba et al. (2011) observed maize grain Se concentration that was up to tenfold higher for soils with high $\mathrm{pH}$ $(>6.5$ ), and this is explained by greater Se availability to plants following greater solubility of selenium

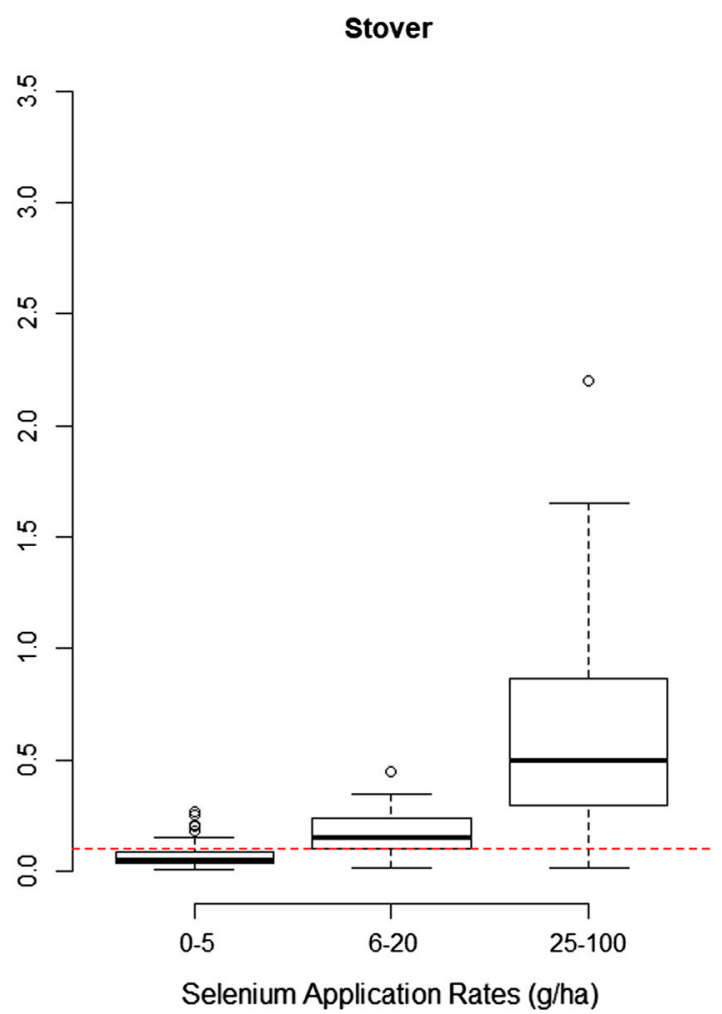

range, while the whiskers show non-outlier range. The red lines show the lower critical limit of Se for humans 
(Se(IV)) species and oxidation to selenate (Se(VI)). They also reported positive correlation between grain Se concentration and soil $\mathrm{pH}$, especially at the high $\mathrm{pH}$.

\section{Copper $(\mathrm{Cu})$ in harvest grains}

Compared with the grain quality of unfertilized maize, the concentration of $\mathrm{Cu}$ increased in maize grain when NPK fertilizer plus secondary and micronutrients (including $\mathrm{Cu}$ ) were applied (Fig. 3). Application of macronutrients alone did not increase significantly the concentration of $\mathrm{Cu}$ in maize grain over that of the control treatment (i.e., confidence limits of means for these treatments are overlapping) (Fig. 3).

\section{Zinc in harvest grains}

Omission of $\mathrm{Zn}$ (farmer practice, (FP) and zinc omission, $\mathrm{Zn} 0$ treatments) has the lowest grain $\mathrm{Zn}$ concentrations (Fig. 4). Application of $\mathrm{Zn}$ without $\mathrm{P}$ (P0) or with low amounts of P (P20) resulted in the highest grain $\mathrm{Zn}$ concentrations. Due to the interactions between $\mathrm{P}$ and $\mathrm{Zn}$ in the soil, the uptake of $\mathrm{Zn}$ by plants decreased as the amount of plant available $\mathrm{P}$ increased. Unfortunately, all the observed maize grain $\mathrm{Zn}$ concentrations (Fig. 4) are below the global

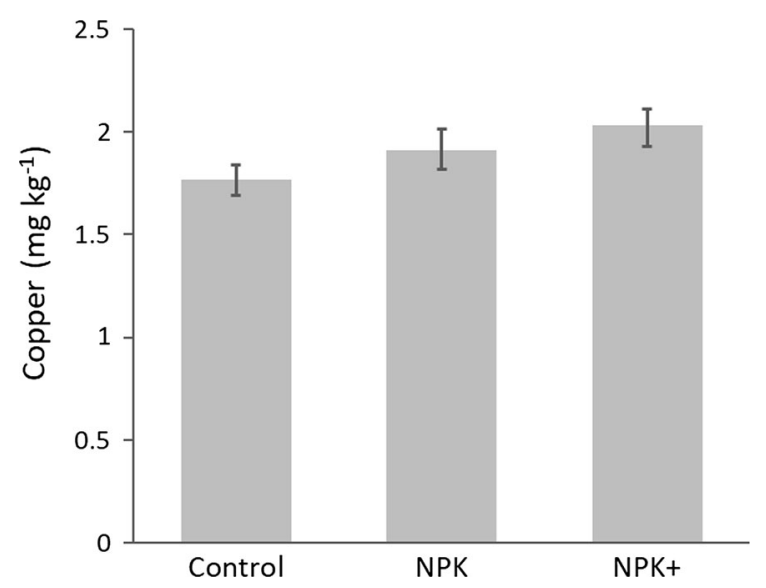

Fig. 3 Effects of NPK fertilizer, and secondary and micronutrients on concentration of copper in maize grain (Zea mays L.) as observed in sub-Saharan Africa (Nigeria and Malawi). Error bars are bootstrap confidence intervals of means. Number of observations varied from 153/156 among the treatments. Control $=$ no fertilizer added, $\mathrm{NPK}=$ fertilizer containing nitrogen $(\mathrm{N})$, phosphorous $(\mathrm{P})$ and potassium $(\mathrm{K}), \mathrm{NPK}+=$ fertilizer containing NPK and one or more micronutrient elements average of $25 \mathrm{mg} \mathrm{Zn} \mathrm{kg}^{-1}$ (Ortiz-Monasterio et al. 2007). Even in southern Africa (Zimbabwe), maize grain $\mathrm{Zn}$ concentrations are still below the concentration target of $38 \mathrm{mg} \mathrm{Zn} \mathrm{kg}^{-1}$ needed to meet human dietary needs by HarvestPlus (Bouis and Welch 2010; Fig. 5). The conclusion by Manzeke et al. (2019) that grain $\mathrm{Zn}$ (and Fe) in food crops in southern Africa is insufficient for adequate human nutrition applies also for other parts of sub-Sahara Africa. An interesting result is that while the maximum grain $\mathrm{Zn}$ is about $33 \mathrm{mg} \mathrm{kg}^{-1}$ regardless of soil $\mathrm{Zn}$ concentrations, the minimum grain $\mathrm{Zn}$ increases with soil $\mathrm{Zn}$. Generally, Manzeke et al. (2019) observed that higher extractable soil $\mathrm{Zn}$ concentration was correlated with a higher grain $\mathrm{Zn}$ concentration in staple crops, with the extractable soil $\mathrm{Zn}$ influenced by management, soil organic matter content, total soil $\mathrm{Zn}$ and $\mathrm{pH}$.

Studies involving $\mathrm{Zn}$ are more common than studies of other nutrients. Evidence has been building that $\mathrm{Zn}$ application, especially as foliar spray, increases wheat grain zinc concentrations, e.g., in Zambia (Zou et al. 2012) and Egypt (El-Dahshouri 2018) and maize grain quality in Egypt (Salem and ElGizawy 2012) and Togo (Nziguheba et al. 2009; Fig. 4). According to Manzeke et al. (2014), Zn-based treatments increased grain $\mathrm{Zn}$ concentrations by $67 \%$ compared to treatments without $\mathrm{Zn}$ application. Joy et al. (2015) showed improvements of maize, rice and wheat grain zinc concentrations of 23, 7 and 19\%, respectively, following soil $\mathrm{Zn}$ application and up to 30, 25 and $63 \%$ following $\mathrm{Zn}$ foliar application. In Nigeria, application of $\mathrm{Zn}$ at different levels resulted in $\mathrm{Zn}$ concentrations in maize shoots ranging between 3.15 and $10.40 \mathrm{mg} \mathrm{kg}^{-1}$, ranges that are still below the critical levels of $25-60 \mathrm{mg} \mathrm{kg}^{-1} \mathrm{Zn}$ (Eteng et al. 2014). Moreover, application of $\mathrm{Zn}$ increased the quality of faba beans (Vicia faba ssp) through enhancing $\mathrm{Zn}$ concentrations in the nodule and upper matured leaves by 0.76 and $31 \mathrm{mg} \mathrm{kg}^{-1}$, respectively, in Ethiopia (Desta et al. 2015) relative to no $\mathrm{Zn}$ application. The increasing $\mathrm{Zn}$ concentration is sometimes associated with increase in grain protein (ElDahshouri 2018; Seadh et al. 2009; El-Habbasha et al. 2015), pointing to the important functions of zinc in protein synthesis in the crop. In Turkey, Cakmak et al. (2010) observed that foliar application of Zn during early stage of seed development maximizes the accumulation of $\mathrm{Zn}$ in grain due to a possible high sink activity for $\mathrm{Zn}$ at this developmental stage. Crop 


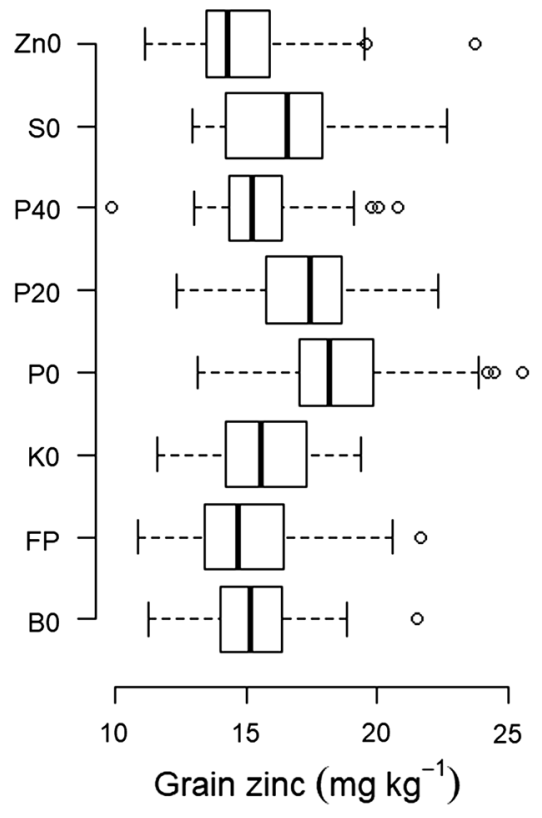

(a)

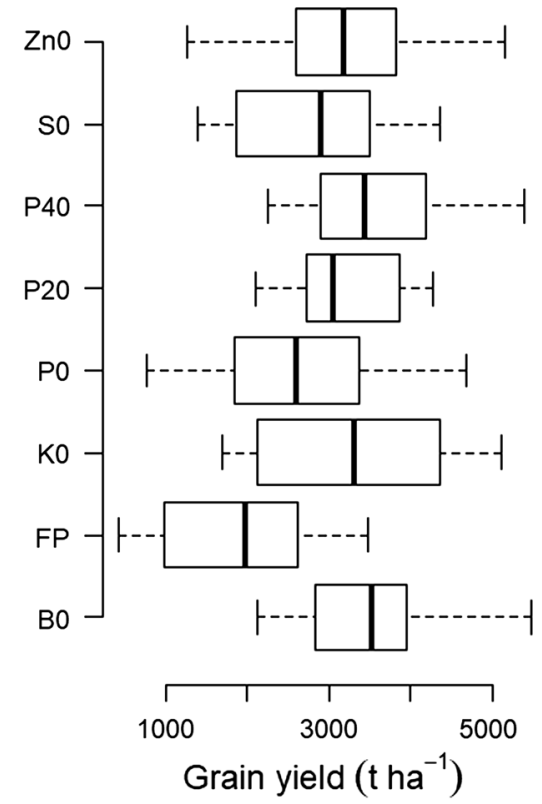

(b)

Fig. 4 Boxplots showing zinc (Zn) concentration in maize (Zea mays L.) grain and the associated yields following nutrient omissions. Nutrient followed by zero means that the nutrient was omitted. FP = farmer practice (not fertilized)

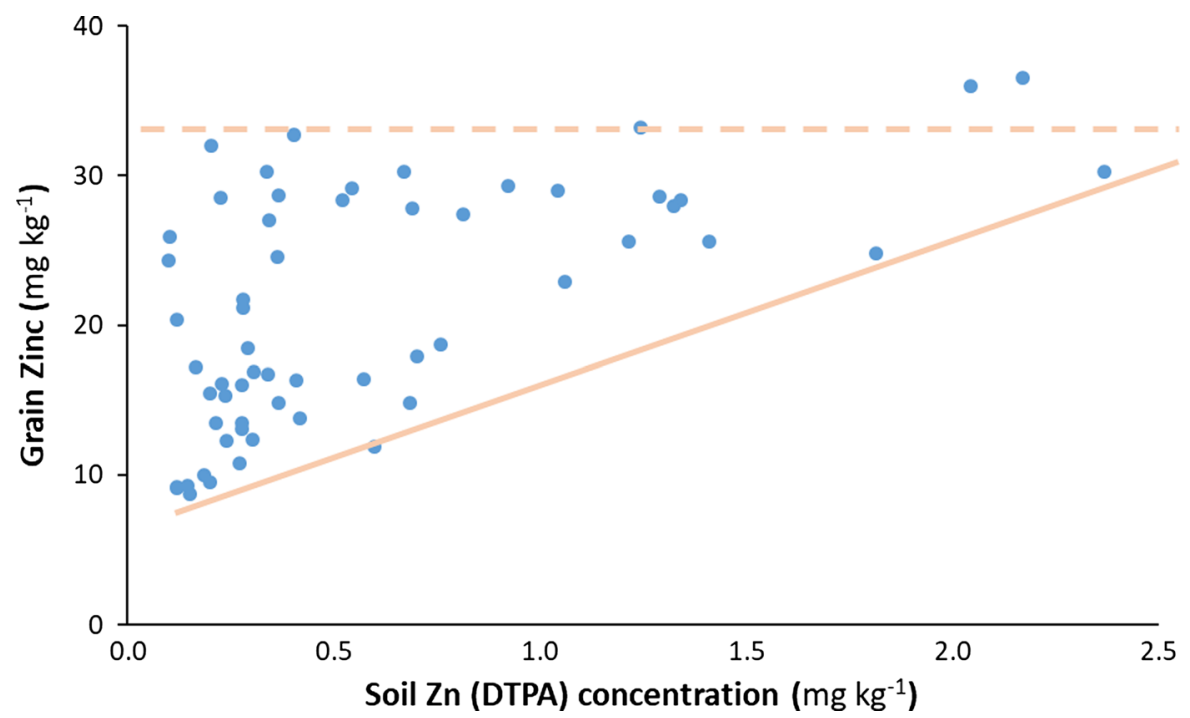

Fig. 5 Grain zinc (Zn) concentrations in maize (Zea mays L.) at different soil $\mathrm{Zn}$ test values for different farms in Zimbabwe. Each data point represents an individual farm. Broken line

growth stage, proper timing, splitting/frequency of application and concentrations, for example, of foliar zinc applications, are important factors influencing effects of micronutrient fertilization (Zhang et al. 2010; Boonchuay et al. 2013; El-Dahshouri 2018). indicates the similar maximum grain $\mathrm{Zn}$ concentrations, while the continuous line indicates trend for the lowest concentrations

Foliar zinc application between panicle initiation of paddy rice and 2 weeks after flowering resulted in higher grain zinc concentration than earlier application (panicle initiation and booting; Boonchuay et al. 2013) indicating more zinc reallocation to seed. 
Similar results are observed for wheat following foliar zinc application after flowering stage compared to before flowering stage (Ozturk et al. 2006; Cakmak et al. 2010; Phattarakul et al. 2012; Li et al. 2014), while Cakmak et al. (2010) obtained highest grain zinc concentrations when zinc was applied at four different growth stages (stem elongation, booting, early milk/dough and anthesis) compared to either two or three growth stages.

The application rates of $\mathrm{Zn}$ fertilizers depends on factors such as the soil chemical and physical properties, form of Zn fertilizer used, application method and crop species/cultivar. The critical level of $\mathrm{Zn}$ in soil below which deficiency occurs ranges from 0.6 to $2.0 \mathrm{mg} \mathrm{Zn} \mathrm{kg}{ }^{-1}$ depending on the $\mathrm{Zn}$ extraction method used (Singh et al. 2005). Application of $\mathrm{Zn}$ in the soil is often higher for zinc sulfate $(2.5-22 \mathrm{~kg} \mathrm{Zn}$ $\mathrm{ha}^{-1}$; Kinaci and Kinaci 2005; Sadeghzadeh 2013) than for chelated forms $\left(0.3-6 \mathrm{~kg} \mathrm{Zn} \mathrm{ha}{ }^{-1}\right.$; Sadeghzadeh 2013). Depending on the $\mathrm{Zn}$ levels, plant $\mathrm{Zn}$ deficiency status can be categorized as definite $\mathrm{Zn}$ deficient $\left(<10 \mathrm{mg} \mathrm{kg}^{-1}\right)$, likely to be deficient $\left(10-15 \mathrm{mg} \mathrm{kg}^{-1}\right)$, likely to be sufficient (15-20 mg kg${ }^{-1}$ ) and sufficient (>20 mg kg-1 of dry matter; Singh et al. 2005).

\section{Sulfur and micronutrients in plant leaves}

Nutrient element concentrations in plant leaves can be good indicators of crop uptake and grain concentrations. Significant effects of fertilizer application on micronutrients are observed on ear leaves of maize. Concentrations of $\mathrm{Mn}$ in ear leaves of maize are enhanced by fertilizer application both with and without secondary and micronutrients (Fig. 6). Both fertilizer treatments resulted in $\mathrm{Mn}$ concentrations above a critical minimum limit of $50 \mathrm{mg} \mathrm{kg}^{-1}$ (Adeoye and Agboola 1985). Ear leaf concentrations of $\mathrm{Zn}$ and $\mathrm{B}$ are not influenced by macronutrients application, but are influenced by further addition of secondary and micronutrients. The concentration of B in maize ear leaves quadrupled when secondary and micronutrients were added to NPK fertilizer although no evidence was yet observed in improvements in the overall productivity. With the application of secondary and micronutrients, the $\mathrm{Zn}$ ear leaf concentrations are on average within the minimum critical limit of $15 \mathrm{mg} \mathrm{kg}^{-1}$ (Singh et al. 2005) and of $16 \mathrm{mg} \mathrm{kg}^{-1}$ (Welch and Graham 2000) although all treatments result in the $\mathrm{Zn}$ concentration above the critical limit of $10 \mathrm{mg} \mathrm{kg}^{-1}$ (Adeoye and Agboola 1985). Besides these micronutrient element concentrations in ear leaves, applying secondary and micronutrients increase sulfur (a secondary nutrient) concentrations in ear leaves relative to the NPK fertilizer treatment. The critical limits of most micronutrients for plant parts and also for soils are not yet determined for African conditions.

As with maize grain yields, minimum plant foliar $\mathrm{Zn}$ concentrations increase with increasing soil $\mathrm{Zn}$ (Fig. 7). Also, the concentration of plant zinc increases with increasing soil $\mathrm{Zn}$ up to about 4-6 mg kg ${ }^{-1}$ of soil test $\mathrm{Zn}$, especially for sorghum, cowpea and finger millet.

Evidence of changes in plant concentrations of micronutrients for SSA is based on experiments conducted mostly in individual farmer's fields or concentrated in specific localities. To make regionwide nutritional changes using agronomic biofortification, major policy interventions are needed. For example, in Finland, a nationwide micronutrient study that involved enrichment of NPK fertilizers with $15 \mathrm{mg} \mathrm{Se} \mathrm{kg}{ }^{-1}$ prompted increased populace intake of selenium (above nutritional recommendations) by occasioning a 15-fold average increase in Se contents in the cereal grains (Alfthan et al. 2015).

Effects of micronutrients on macronutrients use efficiency

Addition of micronutrients ( $\mathrm{S}, \mathrm{Zn}$ and $\mathrm{B}$ ) in customized fertilizer blends (also with $\mathrm{N}, \mathrm{P}$ and $\mathrm{K}$ ) resulted in $50 \%$ increase in yields $\left(+2.4 \mathrm{t} \mathrm{ha}^{-1}\right)$ over commonly recommended NPS fertilizer $(81 \mathrm{~N}, 14 \mathrm{P}$, $6 \mathrm{~S}$ ) pointing to increased utilization of $\mathrm{N}$ and $\mathrm{P}$ at higher rates where response curve would ordinarily level off (Van Vugt 2018). In a study conducted by One Acre Fund (unpublished), addition of customized blend, Mavuno fertilizer (containing NPK (10:26:10) plus secondary nutrients ( $\mathrm{Ca}, \mathrm{Mg}$ and $\mathrm{S}$ ) and micronutrients $(\mathrm{Zn}, \mathrm{Cu}, \mathrm{Mn}, \mathrm{B}$ and $\mathrm{Mo}$ ) resulted in $75 \%$ increase (i.e., from $198 \mathrm{~kg}_{\text {grain }} \mathrm{kg}^{-1} \mathrm{P}$ in control to $347 \mathrm{~kg}$ grain $\mathrm{kg}^{-1} \mathrm{P}$ in the improved blend) in phosphorus use efficiency compared to local fertilizer recommendation. In India, annual application of NP plus $50 \%$ dose of $\mathrm{S}, \mathrm{B}$ and $\mathrm{Zn}$ (i.e., full dose for the micronutrients were as follows: $30 \mathrm{~kg} \mathrm{ha}^{-1}$ for $\mathrm{S}$, $0.5 \mathrm{~kg} \mathrm{ha}^{-1} \mathrm{~B}$ and $10 \mathrm{~kg} \mathrm{ha}^{-1} \mathrm{Zn}$ for maize and 

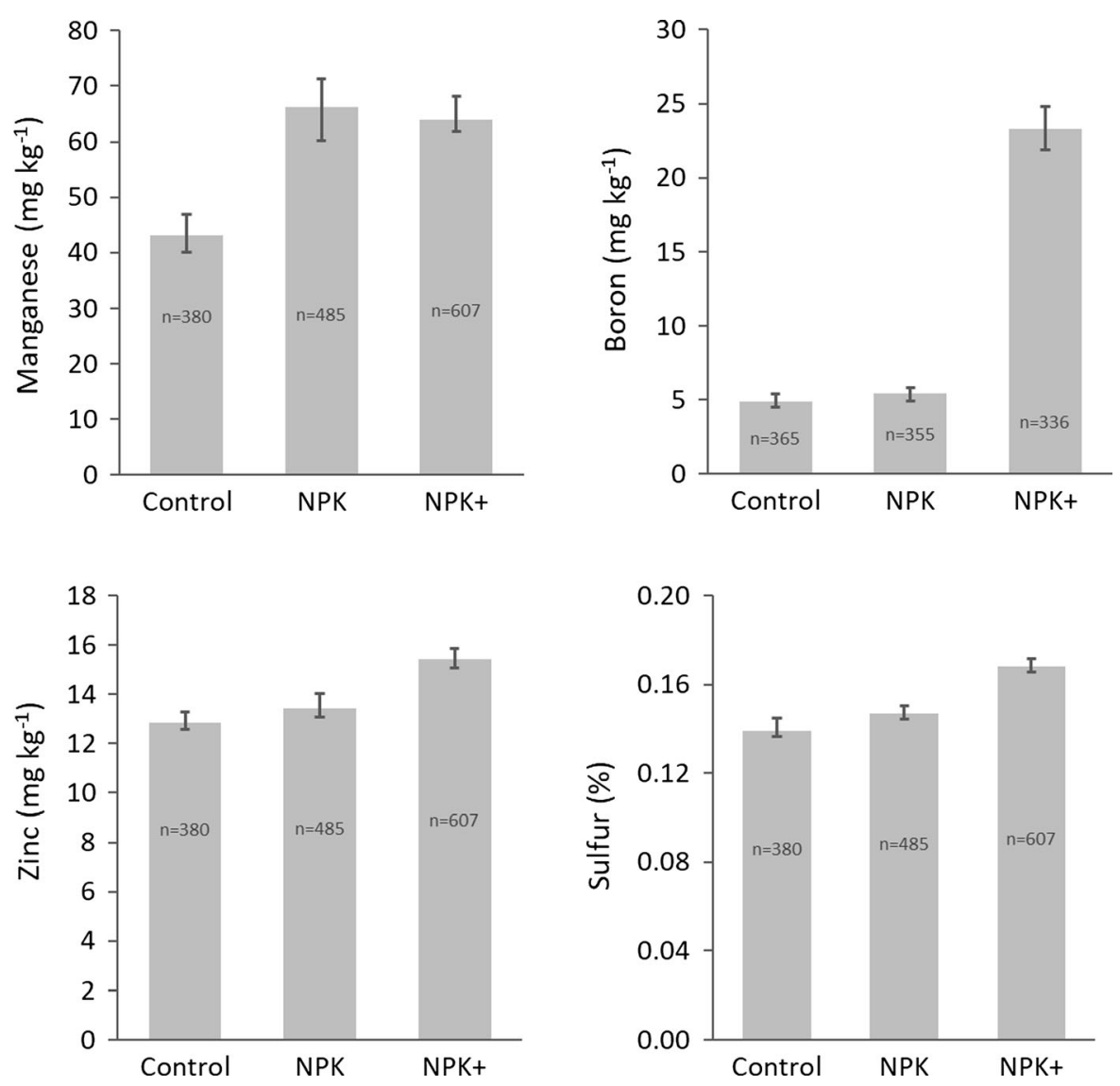

Fig. 6 Effects of fertilizers including secondary and micronutrients on quality of ear leaves of maize (Zea mays L.) as observed in sub-Saharan Africa (Nigeria and Togo). Error bars show bootstrap confidence intervals of means. Control $=$ no

fertilizer added, NPK = fertilizer containing nitrogen $(\mathrm{N})$, phosphorous $(\mathrm{P})$ and potassium $(\mathrm{K}), \mathrm{NPK}+=$ fertilizer containing NPK (and one or more micronutrient elements)

beans. $\mathrm{N}$ and $\mathrm{P}$ were applied as $100 \mathrm{~kg} \mathrm{~N}^{-1}$ and $26 \mathrm{~kg} \mathrm{Pha}^{-1}$ for maize and $30 \mathrm{~kg} \mathrm{~N}$ and $26 \mathrm{~kg} \mathrm{P} \mathrm{ha}^{-1}$ for soybean) increased nitrogen use efficiency in maize by $36.4 \%$ relative to the NP control in maize and $21.7 \%$ in soybean, and also increased phosphorus use efficiency by $36.9 \%$ in maize and $19.4 \%$ in soybean (Chander et al. 2015). In Egypt, Khafagy et al. (2017) observed that including zinc fertilization of 20 and $40 \mathrm{~kg} \mathrm{Zn} \mathrm{ha}^{-1}$ increased rice grain $\mathrm{N}$ uptake by $17 \%$ and $28 \%$, respectively, and similarly improved uptakes of $\mathrm{P}$ and $\mathrm{K}$ relative to the control treatment applied with $\mathrm{N}$ but not zinc. This is in line with ElDahshouri (2018) who found that application of zinc increased macronutrient concentrations in wheat cultivars. In addition, application of zinc resulted to $17 \%$ increase in nitrogen use efficiency (i.e., from $43 \mathrm{~kg}$

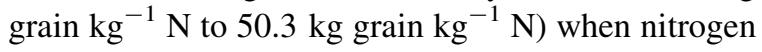
was applied during chickpea seed-filling stage, and

$20 \%$ increase in nitrogen use efficiency (i.e., from 40.7 to $48.7 \mathrm{~kg}_{\text {grain }} \mathrm{kg}^{-1} \mathrm{~N}$ ) when nitrogen was applied during the flowering stage (El-Habbasha et al. 2015), also in Egypt. Addition of NPK + micronutrients increased nitrogen use efficiency and its apparent recovery for wheat by $39 \%$ and $36 \%$, respectively, compared to application of only NPK (Malakouti 2008).

Profitability of micronutrient fertilization

Crop response and profitability of micronutrient fertilization can often be underestimated. In some cases, increase in crop quality can be realized without increase in productivity, and vice versa. For example, despite the increase in maize grain quality following Se application, no significant increase in grain and stover yields was realized in Malawi (Chilimba et al. 


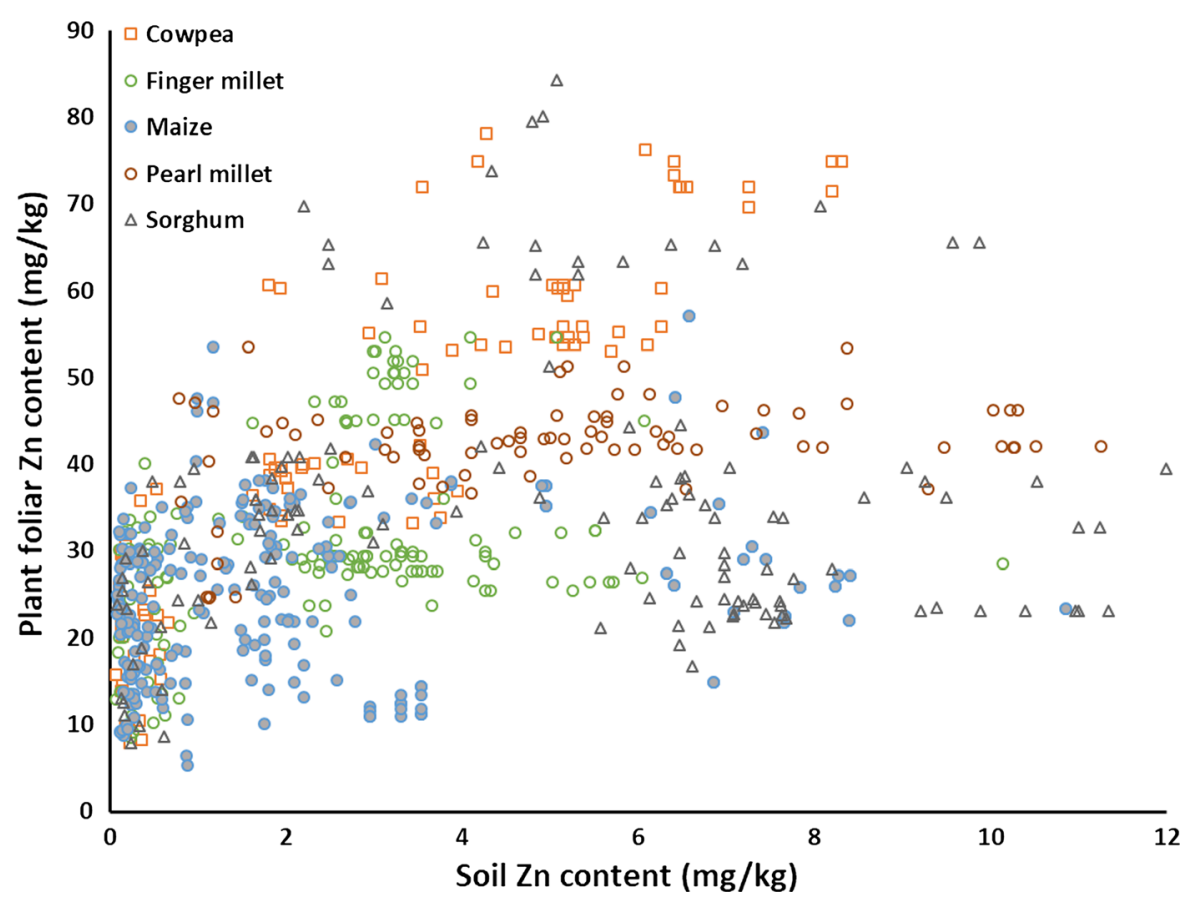

Fig. 7 Concentrations of plant zinc for different crops at different soil $\mathrm{Zn}$ values for OFRA study locations across subSahara Africa. All the samples are derived from treatments applied with $\mathrm{N}, \mathrm{P}$ and $\mathrm{K}$. The crops are maize (Zea mays L.),

2012). De Valença et al. (2017) confirmed that the application of Se-enriched fertilizers had potential to enhance Se concentrations in both maize and wheat grains, but not the yields. The fact that Se did not affect yields is probably due to the fact that this element is not essential for crop plants. On the other hand, the application of $\mathrm{Zn}$ fertilizer can improve not only productivity but grain $\mathrm{Zn}$ concentration by up to three to fourfold (Cakmak 2008). These quality aspects are not taken into account in our profitability assessment.

Most studies in SSA have applied micronutrients to crops as basal at planting. This application method often demands high application rates (higher costs) due to reduced recovery efficiency of applied micronutrients than with foliar application. On the other hand, soil application can result in positive residual effects on crop yield and quality which are commonly not assessed (an underestimation of economic benefits).

Application of secondary and micronutrients to maize has positive net benefits for $70 \%, 85 \%, 80 \%$ and $75 \%$ of the cases for combined secondary and micronutrients (i.e., combined), $\mathrm{Cu}, \mathrm{Zn}$ and $\mathrm{S}$, cowpea (Vigna unguiculata L.), pearl millet (Pennisetum glaucum), finger millet (Eleusine coracana) and sorghum (Sorghum bicolor L.)

respectively (Fig. 8). Application of gypsum to maize (as a source of $\mathrm{S}$ but also contains $\mathrm{Ca}$ ) resulted in positive net benefits in $80 \%$ of the cases. Positive net benefits of $\mathrm{S}$ in wheat production $(n=36)$, reaching a maximum of US\$ 700, were observed in $94 \%$ of the cases (data not shown). High profitability is realized when low amounts of secondary and micronutrients are applied and/or resulting crop yield improvements are high. Unlike for combined secondary and micronutrients and $\mathrm{Zn}$ applications, $\mathrm{S}$ application is profitable across all soil types except in the fertile vertisols (Fig. 9).

Factors affecting crop response to micronutrient applications

Factors such as source of the secondary and micronutrient and the mode of application such as through soil or foliar and the timing of application to crop development stages are discussed in the previous sections. A few more factors are presented here. 


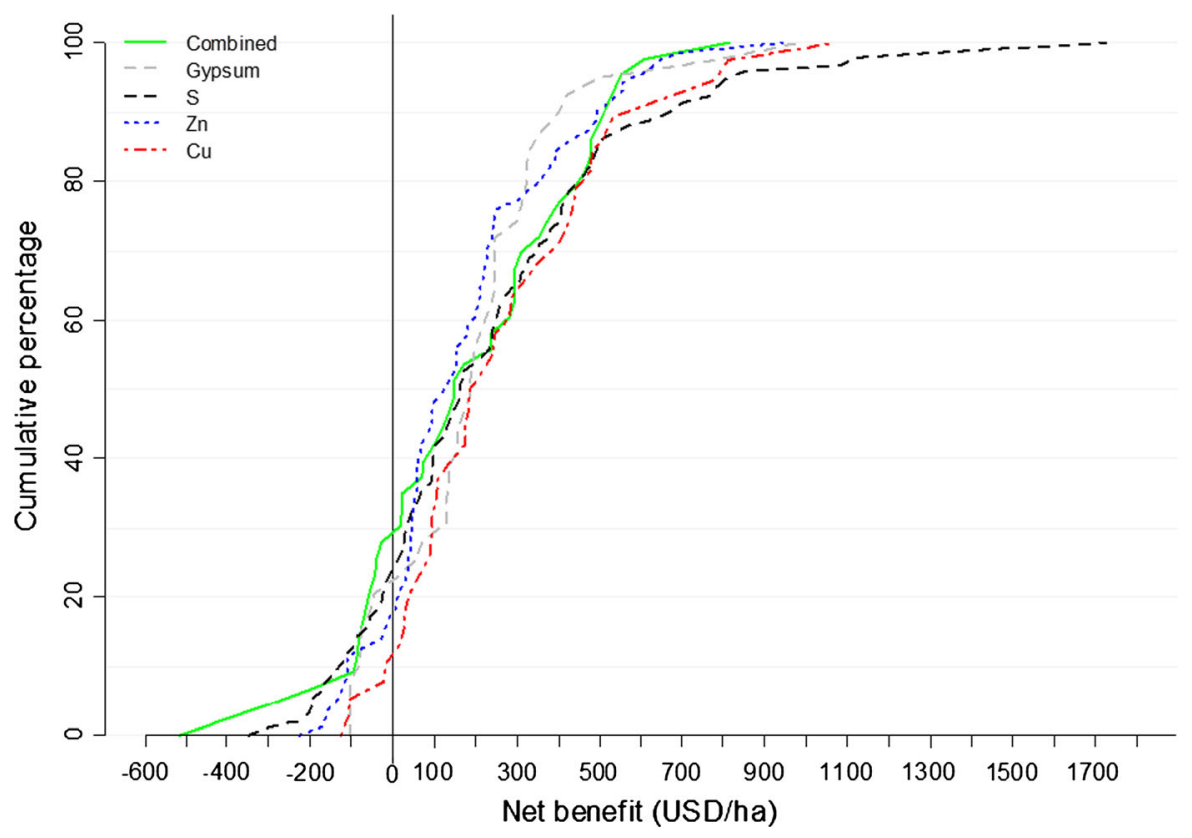

Fig. 8 Distributions of net benefits and the associated cumulative percentages for combined secondary and micronutrients (combined), $\mathrm{S}, \mathrm{Zn}$ and $\mathrm{Cu}$ as observed in SSA for maize. $N=44$ for combined, 95 for $\mathrm{S}, 72$ for $\mathrm{Zn}, 39$ for $\mathrm{Cu}$ and 44 for gypsum.
Black vertical line indicates zero benefit value when no benefits or losses are incurred. Few points where maize yield was $>10 \mathrm{t}$ $\mathrm{ha}^{-1}$ were considered as erroneous and therefore omitted as this is not common in the region
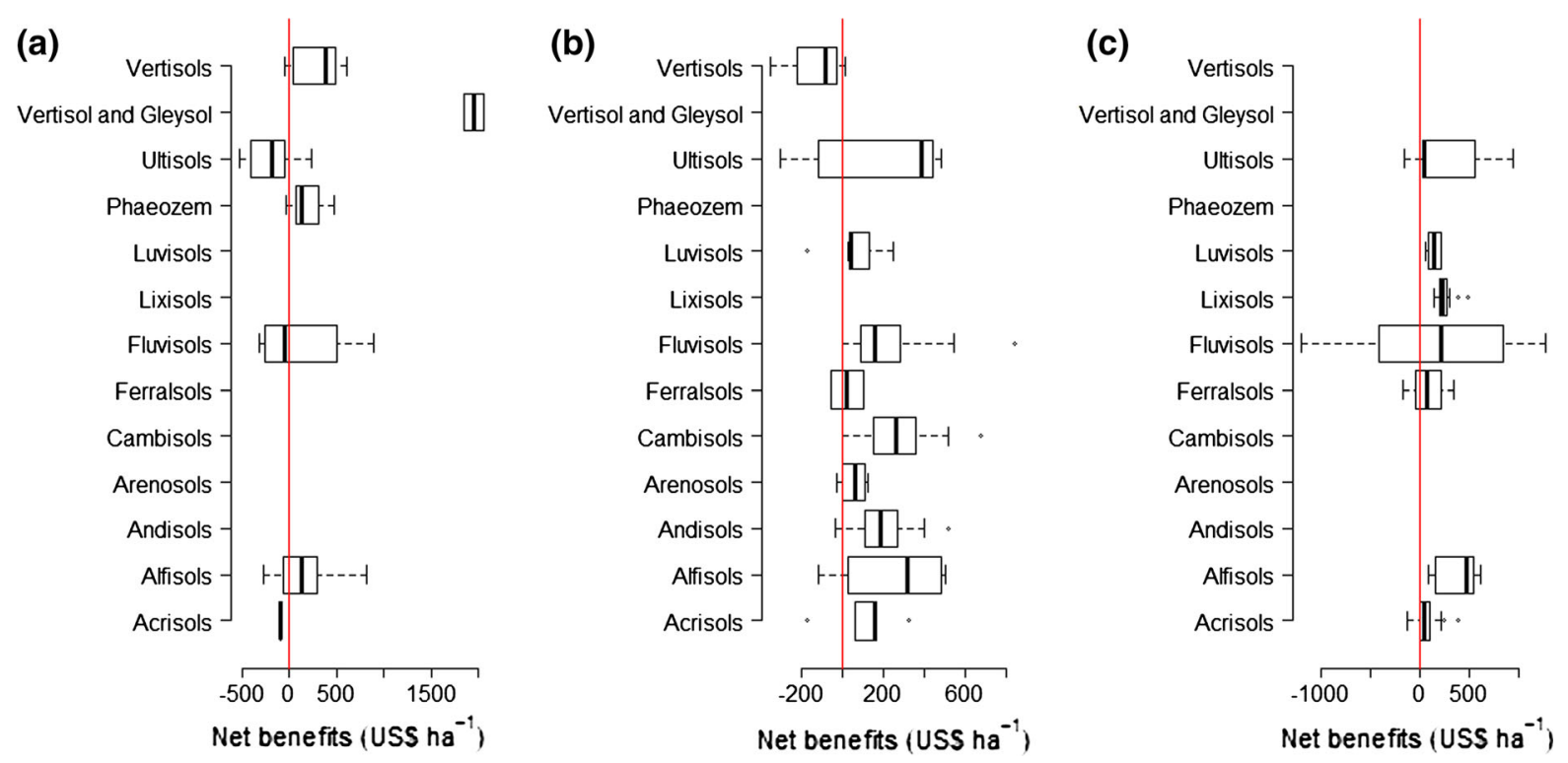

Fig. 9 Range of net profits observed with a combined secondary and micronutrients, b S and $\mathbf{c}$ Zn as observed in SSA. Red lines indicate zero benefit value when no benefits or losses are incurred. Data used are for all crops 


\section{Crop species and cultivars}

Variations in crop response to micronutrient applications may exist not only with different crops, but even with different cultivars of the same crop. In Egypt, zinc concentrations in wheat grains were found to vary with different wheat varieties planted (El-Habbasha et al. 2015). Besides wheat, variations in grain $\mathrm{Zn}$ concentrations in different rice germplasms have been reported (Welch and Graham 2002).

\section{Soil properties}

The plant available micronutrient content in the soil often shows considerable spatial variation (Hengl et al. 2017). This is probably the cause of at least part of the observed variation in crop response to micronutrient fertilization (see, for example, Figs. 2, 5). Where a nutrient element is severely deficient in the soil, the effect of fertilization is likely to be larger compared to when the soil nutrient supply is moderate or sufficient. Soil laboratories often use critical levels of plant available element concentrations in the soil, below which application of fertilizer containing the element is recommended. Soil nutrient element interactions can reduce efficiency and profitability of specific micronutrients. For example, elevated availability of soil $\mathrm{P}$ affects zinc availability to plants by precipitating the zinc, occasioning deficiency, and soil $\mathrm{pH}$ is important for the availability of most nutrient elements to crop roots.

Effect on soil microbiota and environmental impacts

In SSA, there are no studies focused on direct effects of different micronutrient concentrations on soil microbial parameters and enzyme activities or on long-term environmental impacts. Nevertheless, there is evidence from elsewhere that when applied in the right dosage, micronutrient elements benefit soil biodiversity including soil microbial colonization, growth, mycorrhizal development, symbiotic nitrogen fixation and nodulation of legumes (Pollard et al. 1977; Alam et al. 2015; Farooq et al. 2018). The application of moderate amounts of boron up to $3 \mathrm{~kg} \mathrm{ha}^{-1}$ increases soil fungal and bacterial populations, and phosphatase and dehydrogenase enzyme activities by between 18 and $34 \%$ during different growth periods relative to no application (Bilen et al. 2011). Application of $0.5 \mathrm{mg} \mathrm{kg}^{-1}$ of Mo increased nitrogenase enzyme activity $(71 \%)$ and root nodule number (63\%; Alam et al. 2015), while application of moderate $\mathrm{Zn}\left(15 \mathrm{~kg} \mathrm{Zn} \mathrm{ha}^{-1}\right)$ increased nodule indices of cowpea by at least 38\% (Upadhyay and Singh 2016). At high concentrations, for example, of boron (application of $9 \mathrm{~kg} \mathrm{~B} \mathrm{ha}^{-1}$ ), the microbial growth and enzyme activities decrease due to impaired functions of cell membrane, and soil microbial structure is altered (Nable et al. 1997; Nelson and Mele 2007; Bilen et al. 2011; Vera et al. 2019). Similarly, high amounts of zinc decrease microbial biomass (by $41 \%$; Chander and Brookes 1993) and reduce microbial species richness (by 38.5\%; Moffett et al. 2003).

Long-term use of some chemical sources for restoring micronutrient deficiencies, for instance, zinc chelate-EDTA, may pose environmental challenges due to their characteristic low biodegradation and increased environmental persistence (Egli 2001; Meers et al. 2005). Prolonged application of ammonium sulfate fertilizers as a source of sulfur can alter soil $\mathrm{pH}$ and prompt ammonium accumulation to levels inhibitory to microbial communities, reducing soil microbial biomass and abundance (Geisseler and Scow 2014).

Decision support for micronutrient application at multiple scales

\section{Site-specific micronutrient fertilization}

The core principle of precision crop production is to adapt crop management, including micronutrient fertilization to site-specific growth conditions (Gebbers and Adamchuk 2010). Consequently, nutrient use efficiency and profitability can be improved, and crop nutritional quality goals can be achieved to a larger degree, compared to if uniform rates were applied over large areas. The latter likely means unnecessary application (and poor profit) in some areas and at the same time insufficient application in other areas (the Guldilock problem; Foley et al. 2011). The core principles (and the expected benefits) apply at multiple spatial scales even if the specific term precision agriculture often refers to variable rate application within individual fields. 


\section{Decision support at multiple scales}

Decisions on micronutrient fertilization are made or guided, directly or indirectly, at multiple spatial scales; national and sub-national authorities may decide on subsidies and for different inputs to crop production and may legislate on rates and types of fertilizers and lime products to important crops. Fertilizer companies may target their selling of specific fertilizer blends to regional needs and thus control what compounds are available in different regions, private and governmental extension service providers may provide advice on micronutrient application and individual farmers make the final decision to apply the fertilizer. At all these levels, decision support is needed and there are several options available. Recently, digital soil maps of several secondary and micronutrient elements $(\mathrm{Ca}, \mathrm{Mg}, \mathrm{S}$, $\mathrm{Fe}, \mathrm{Mn}, \mathrm{Zn}, \mathrm{Cu}, \mathrm{B}$ ) were published, covering the SSA (Hengl et al. 2015), providing spatial information on risks for micronutrient deficiencies. These can be further improved for adequate use in smaller regions by local adaptation (see principles by Söderström et al. 2017). There is also an option to collect new data by direct (soil or crop sampling + laboratory analysis) or indirect (proximal sensor measurements of soil or crop) measurements to diagnose micronutrient deficiencies at point locations (Nyambura et al. 2015; Towett et al. 2016; Piikki et al. 2016). It is, however, not enough that the decision support (the maps and the methods) exists. These need to be provided in a form that suits the different stakeholders, where also tailored decisions on fertilizations are made. New decision support systems are needed to bridge the gap between data and decisions.

The data presented on plant quality and profitability enhancement in this study and the productivity improvements shown earlier (Kihara et al. 2017) are strong arguments in favor of secondary and micronutrient fertilization. However, when linking soils to human malnutrition in SSA, Berkhout et al. (2019) concluded that although there is a significant positive link between soil micronutrient contents and malnutrition, agronomic biofortification is cost-ineffective. This claim will need to be further explored in the future to ascertain the bioavailability and uptake of the micronutrient-rich food and feed produced under agronomic biofortification.

\section{Conclusion}

The synthesis of scientific data and literature shows that:

- There is widespread but variable micronutrient deficiencies in arable soils in SSA, and more than one micronutrient elements are often deficient at the same geographic location.

- Application of $\mathrm{Zn}$ and Se increased micronutrient concentrations in harvested cereal and legume grains, but the concentrations varied considerably as the dataset used included multiple cultivars and sites.

- It was profitable to apply fertilizers containing micronutrient elements. Application of $S$ was profitable in almost all cases, while the profitability of $\mathrm{Zn}$ application was more variable. Profitability also varied with soil type.

- There is a general lack of public information on how application of other nutrients than N, P and K affects crop yield and nutritional quality in SSA. Most public information available is on the effects of $\mathrm{Zn}$ application.

- To raise the nutritional quality of major food crops in SSA while striving toward a resource use efficient and profitable crop production, fertilizer sources/types and rates need to be tailored to local soil and cropping conditions, crop and cultivar type (i.e., need for customized blends).

- Transforming the current food systems to take into account human nutritional requirements, especially through agronomic approaches, is urgently needed.

- Although the call for more work to link fertilizer technology and improvement of the nutritional quality of staple food crops that feed the world's malnourished poor has been made since 2012, there is still a dearth of knowledge on this, especially in SSA.

Acknowledgements We thank the AgriFoSe2030 programme and Sida for the financial support provided. We acknowledge also individual scientists such as Dr. Generose Nziguheba of IITA and Prof. Charles Wortmann of Nebraska for sharing some of the datasets used in this study.

Funding This study was funded by AgriFoSe2030 programme and Sida. 


\section{Compliance with ethical standards}

Conflict of interest The authors declare that they have no conflict of interest.

Open Access This article is licensed under a Creative Commons Attribution 4.0 International License, which permits use, sharing, adaptation, distribution and reproduction in any medium or format, as long as you give appropriate credit to the original author(s) and the source, provide a link to the Creative Commons licence, and indicate if changes were made. The images or other third party material in this article are included in the article's Creative Commons licence, unless indicated otherwise in a credit line to the material. If material is not included in the article's Creative Commons licence and your intended use is not permitted by statutory regulation or exceeds the permitted use, you will need to obtain permission directly from the copyright holder. To view a copy of this licence, visit http://creativecommons.org/licenses/by/4.0/.

\section{References}

Abe, S. S., Buri, M. M., Issaka, R. N., Kiepe, P., \& Wakatsuki, T. (2010). Soil fertility potential for rice production in West African lowlands. Japan Agricultural Research, 44, 343-355.

Adeoye, G. O., \& Agboola, A. A. (1985). Critical levels for soil $\mathrm{pH}$, available $\mathrm{P}, \mathrm{K}, \mathrm{Zn}$ and $\mathrm{Mn}$ and maize ear-leaf content of $\mathrm{P}, \mathrm{Cu}$ and $\mathrm{Mn}$ in sedimentary soils of South-Western Nigeria. Fertilizer Research, 6, 65-71.

Alam, F., Kim, T. Y., Kim, S. Y., Alam, S. S., Pramanik, P., Kim, P. J., et al. (2015). Effect of molybdenum on nodulation, plant yield and nitrogen uptake in hairy vetch (Vicia villosa Roth). Soil Science and Plant Nutrition, 61(4), 664-675.

Alfthan, G., Eurola, M., Ekholm, P., Venäläinen, E. R., Root, T., Korkalainen, K., et al. (2015). Effects of nationwide addition of selenium to fertilizers on foods, and animal and human health in Finland: From deficiency to optimal selenium status of the population. Journal of Trace Elements in Medicine and Biology, 31, 142-147.

Berkhout, E., Malan, M., \& Kram, T. (2017). Micronutrients for agricultural intensification. Is sub-Saharan Africa at risk?. The Hague: PBL Netherlands Environmental Assessment Agency.

Berkhout, E. D., Malan, M., \& Kram, T. (2019). Better soils for healthier lives? An econometric assessment of the link between soil nutrients and malnutrition in Sub-Saharan Africa. PLoS ONE, 14(1), e0210642. https://doi.org/10. 1371/journal.pone.0210642.

Bilen, S., Bilen, M., \& Bardhan, S. (2011). The effects of boron management on soil microbial population and enzyme activities. African Journal of Biotechnology, 10(27), 5311-5319.

Boonchuay, P., Cakmak, I., Rerkasem, B., \& Prom-U-Thai, C. (2013). Effect of different foliar zinc application at different growth stages on seed zinc concentration and its impact on seedling vigor in rice. Soil Science and Plant Nutrition, 59(2), 180-188.
Bouis, H. E., \& Welch, R. M. (2010). Biofortification- a sustainable agricultural strategy for reducing micronutrient malnutrition in the global south. Crop Science, 50(Supplement_1), S-20.

Buri, M. M., Masunaga, T., \& Wakatsuki, T. (2000). Sulfur and zinc levels as limiting factors to rice production in West Africa lowlands. Geoderma, 94, 23-42. https://doi.org/10. 1016/S0016-7061(99)00076-2.

Cakmak, I. (2008). Enrichment of cereal grains with zinc: agronomic or genetic biofortification? Plant and Soil, 302(1-2), 1-7.

Cakmak, I., Kalayci, M., Kaya, Y., Torun, A. A., Aydin, N., Wang, Y., et al. (2010). Biofortification and localization of zinc in wheat grain. Journal of Agricultural and Food Chemistry, 58(16), 9092-9102.

Cakmak, I., McLaughlin, M. J., \& White, P. (2017). Zinc for better crop production and human health. Plant and Soil, $411,1-4$.

Chaguala, P. A., Nobela, L., Aline, S., Maria, R., \& Buque, I. (2011). Maize response to macro-and micro-nutrients in two different agro-ecological zones in Mozambique. In 10th African crop science conference proceedings, Maputo, Mozambique, 10-13 October 2011. African Crop Science Society.

Chander, K., \& Brookes, P. C. (1993). Residual effects of zinc, copper and nickel in sewage sludge on microbial biomass in a sandy loam. Soil Biology \& Biochemistry, 25, 1231-1239.

Chander, G., Wani, S. P., Sahrawat, K. L., \& Rajesh, C. (2015). Enhanced nutrient and rainwater use efficiency in maize and soybean with secondary and micronutrient amendments in the rainfed semi-arid tropics. Archives of Agronomy and Soil Science, 61(3), 285-298.

Chilimba, A. D., Young, S. D., Black, C. R., Meacham, M. C., Lammel, J., \& Broadley, M. R. (2012). Agronomic biofortification of maize with selenium (Se) in Malawi. Field Crops Research, 125, 118-128.

Chilimba, A. D., Young, S. D., Black, C. R., Rogerson, K. B., Ander, E. L., Watts, M. J., et al. (2011). Maize grain and soil surveys reveal suboptimal dietary selenium intake is widespread in Malawi. Scientific Reports, 1, 72.

Chilimba, A. D., Young, S. D., \& Joy, E. J. (2014). Agronomic biofortification of maize, soybean and groundnut with selenium in intercropping and sole cropping systems. African Journal of Agricultural Research, 9(50), 3620-3626.

Chilimba, A. D. C., \& Chirwa, I. M. D. (2000). Sulphur nutrient deficiency amendment for maize production in Malawi. Report for Chitedze Research Station. Ministry of Agriculture, Lilongwe.

Curtin, D., Hanson, R., Lindley, T. N., \& Butler, R. C. (2006). Selenium concentration in wheat (Triticum aestivum) grain as influenced by method, rate, and timing of sodium selenate application. New Zealand Journal of Crop and Horticultural Science, 34(4), 329-339.

Dar, W. D. (2004). Macro-benefits from micronutrients for grey to green revolution in agriculture. In IFA international symposium on micronutrients, 23-25 February 2004, New Delhi, India.

De Valença, A. W., Bake, A., Brouwer, I. D., \& Giller, K. E. (2017). Agronomic biofortification of crops to fight hidden 
hunger in sub-Saharan Africa. Global Food Security, 12, $8-14$.

Desta, Y., Habtegebrial, K., \& Weldu, Y. (2015). Inoculation, phosphorous and zinc fertilization effects on nodulation, yield and nutrient uptake of Faba bean (Vicia faba L.) grown on calcaric cambisol of semiarid Ethiopia. Journal of Soil Science and Environmental Management, 6(1), 9-15.

Dimkpa, C. O., \& Bindraban, P. S. (2016). Fortification of micronutrients for efficient agronomic production: a review. Agronomy for Sustainable Development, 36(1), 7.

Egli, T. (2001). Biodegradation of metal-complexing aminopolycarboxylic acids. Journal of Bioscience and Bioengineering, 92(2), 89-97.

El-Dahshouri, M. F. (2018). Effect of zinc foliar application at different physiological growth stages on yield and quality of wheat under sandy soil conditions. Agricultural Engineering International: CIGR Journal, 19(5), 193-200.

El-Habbasha, S. F., Badr, E. A., \& Latef, E. A. (2015). Effect of zinc foliar application on growth characteristics and grain yield of some wheat varieties under $\mathrm{Zn}$ deficient sandy soil condition. International Journal of ChemTech Research, $8(6), 452-458$.

Eteng, E. U., Asawalam, D. O., \& Ano, A. O. (2014). Effect of $\mathrm{Cu}$ and $\mathrm{Zn}$ on maize (Zea mays L.) yield and nutrient uptake in coastal plain sand derived soils of southeastern Nigeria. Open Journal of Soil Science, 4, 235-245. https:// doi.org/10.4236/ojss.2014.47026.

Farooq, M., Rashid, A., Nadeem, F., Stuerz, S., Asch, F., Bell, R. W., et al. (2018). Boron nutrition of rice in different production systems. A review. Agronomy for Sustainable Development, 38(3), 25.

Foley, J. A., Ramankutty, N., Brauman, K. A., Cassidy, E. S., Gerber, J. S., Johnston, M., et al. (2011). Solutions for a cultivated planet. Nature, 478(7369), 337.

Gebbers, R., \& Adamchuk, V. I. (2010). Precision agriculture and food security. Science, 327(5967), 828-831.

Geisseler, D., \& Scow, K. M. (2014). Long-term effects of mineral fertilizers on soil microorganisms-A review. Soil Biology \& Biochemistry, 75, 54-63.

Goudia, B. D., \& Hash, C. T. (2015). Breeding for high grain Fe and $\mathrm{Zn}$ levels in cereals. International Journal of Innovation and Applied Studies, 12(2), 342-354.

Habtegebrial, K., \& Singh, B. R. (2009). Response of wheat cultivars to nitrogen and sulfur for crop yield, nitrogen use efficiency and protein quality in the semiarid region. Journal of Plant Nutrition, 32, 1768-1787.

Hengl, T., Heuvelink, G. B., Kempen, B., Leenaars, J. G., Walsh, M. G., Shepherd, K. D., et al. (2015). Mapping soil properties of Africa at $250 \mathrm{~m}$ resolution: Random forests significantly improve current predictions. PLOS ONE, 10(6), e0125814.

Hengl, T., Leenaars, J. G., Shepherd, K. D., Walsh, M. G., Heuvelink, G. B., Mamo, T., et al. (2017). Soil nutrient maps of Sub-Saharan Africa: Assessment of soil nutrient content at $250 \mathrm{~m}$ spatial resolution using machine learning. Nutrient Cycling in Agroecosystems, 109(1), 77-102.

Joy, E. J., Stein, A. J., Young, S. D., Ander, E. L., Watts, M. J., \& Broadley, M. R. (2015). Zinc-enriched fertilisers as a potential public health intervention in Africa. Plant and
Soil, 389(1-2), 1-24. https://doi.org/10.1007/s11104-0152430-8.

Khafagy, E. E. E., Mosaad, I. S. M., \& Seadh, A. K. (2017). Interaction effect between mineral zinc-nitrogen fertilization mixture and organic fertilization as compost on yield, nutrients uptake of rice and some soil properties. Agricultural Engineering International: CIGR Journal, Special issue: $302-309$.

Kihara, J., Huising, J., Nziguheba, G., Waswa, B. S., Njoroge, S., Kabambe, V., et al. (2016). Maize response to macronutrients and potential for profitability in sub-Saharan Africa. Nutrient Cycling in Agroecosystems, 105(3), $171-181$.

Kihara, J., Sileshi, G. W., Nziguheba, G., Kinyua, M., Zingore, S., \& Sommer, R. (2017). Application of secondary nutrients and micronutrients increases crop yields in sub-Saharan Africa. Agronomy for Sustainable Development, 37, 25 .

Kinaci, G., \& Kinaci, E. (2005). Effect of zinc application on quality traits of barley in semi-arid zones of Turkey. Plant Soil and Environment, 51(7), 328.

Li, M., Yang, X. W., Tian, X. H., Wang, S. X., \& Chen, Y. L. (2014). Effect of nitrogen fertilizer and foliar zinc application at different growth stages on zinc translocation and utilization efficiency in winter wheat. Cereal Research Communications, 42(1), 81-90.

Lisuma, J. B., Semoka, J. M., \& Semu, E. (2006). Maize yield response and nutrient uptake after micronutrient application on a volcanic soil. Agronomy Journal, 98(2), 402-406.

Lyons, G., Stangoulis, J., \& Graham, R. (2003). High-selenium wheat: Biofortification for better health. Nutrition Research Reviews, 16(1), 45-60.

Malakouti, M. J. (2008). The effect of micronutrients in ensuring efficient use of macronutrients. Turkish Journal of Agriculture and Forestry, 32(3), 215-220.

Manzeke, G. M., Mapfumo, P., Mtambanengwe, F., Chikowo, R., Tendayi, T., \& Cakmak, I. (2012). Soil fertility management effects on maize productivity and grain zinc content in smallholder farming systems of Zimbabwe. Plant and Soil, 361(1-2), 57-69.

Manzeke, G. M., Mtambanengwe, F., Nezomba, H., \& Mapfumo, P. (2014). Zinc fertilization influence on maize productivity and grain nutritional quality under integrated soil fertility management in Zimbabwe. Field Crops Research, 166, 128-136.

Manzeke, G. M., Mtambanengwe, F., Watts, M. J., Hamilton, E. M., Lark, R. M., Broadley, M. R., et al. (2019). Fertilizer management and soil type influence grain zinc and iron concentration under contrasting smallholder cropping systems in Zimbabwe. Scientific Reports, 9, 6445. https:// doi.org/10.1038/s41598-019-42828-0.

McCall, M. K. (1985). The significance of distance constraints in peasant farming systems with special reference to subSaharan Africa. Applied Geography, 5(4), 325-345.

Meers, E., Ruttens, A., Hopgood, M. J., Samson, D., \& Tack, F. M. G. (2005). Comparison of EDTA and EDDS as potential soil amendments for enhanced phytoextraction of heavy metals. Chemosphere, 58(8), 1011-1022.

Misiko, A. A. (2012). An investigation of factors influencing performance of agro-input enterprises in Kakamega County, Kenya. M.Sc. Thesis. 
Moffett, B. F., Nicholson, F. A., Uwakwe, N. C., Chambers, B. J., Harris, J. A., \& Hill, T. C. (2003). Zinc contamination decreases the bacterial diversity of agricultural soil. FEMS Microbiology Ecology, 43(1), 13-19.

Nable, R. O., Bañuelos, G. S., \& Paull, J. G. (1997). Boron toxicity. Plant and Soil, 193(1-2), 181-198.

Nelson, D. R., \& Mele, P. M. (2007). Subtle changes in rhizosphere microbial community structure in response to increased boron and sodium chloride concentrations. Soil Biology \& Biochemistry, 39(1), 340-351.

Nyambura, M., Towett, E., Sila, A., Shepherd, K., Keskinen, R., \& Esala, M. (2015). Potential of MIR, TXRF and XRD as complementary techniques for assessment of soil properties. European Journal of Nutrition \& Food Safety, 5(5), 794-795.

Nziguheba, G., Tossah, B. K., Diels, J., Franke, A. C., Aihou, K., Iwuafor, E. N., et al. (2009). Assessment of nutrient deficiencies in maize in nutrient omission trials and long-term field experiments in the West African Savanna. Plant and Soil, 314(1-2), 143.

Ortiz-Monasterio, J. I., Palacios-Rojas, N., Meng, E., Pixley, K., Trethowan, R., \& Pena, R. J. (2007). Enhancing the mineral and vitamin content of wheat and maize through plant breeding. Journal of Cereal Science, 46(3), 293-307.

Ozturk, L., Yazici, M. A., Yucel, C., Torun, A., Cekic, C., Bagci, A., et al. (2006). Concentration and localization of zinc during seed development and germination in wheat. Physiologia Plantarum, 128(1), 144-152.

Pfeiffer, W. H., \& McClafferty, B. (2007). Biofortification: Breeding micronutrient-dense crops. In M. S. Kang \& P. M. Priyadarshan (Eds.), Breeding major food staples for the 21st century (pp. 61-91). Blackwell.

Phattarakul, N., Rerkasem, B., Li, L. J., Wu, L. H., Zou, C. Q., Ram, H., et al. (2012). Biofortification of rice grain with zinc through zinc fertilization in different countries. Plant and Soil, 361(1-2), 131-141.

Piikki, K., Söderström, M., Eriksson, J., Muturi John, J., Ireri Muthee, P., Wetterlind, J., et al. (2016). Performance evaluation of proximal sensors for soil assessment in smallholder farms in Embu County. Kenya. Sensors, 16(11), 1950.

Pollard, A. S., Parr, A. J., \& Loughman, B. C. (1977). Boron in relation to membrane function in higher plants. Journal of Experimental Botany, 28(4), 831-841.

Ram, H., Sohu, V. S., Cakmak, I., Singh, K., Buttar, G. S., Sodhi, G. P. S., et al. (2015). Agronomic fortification of rice and wheat grains with zinc for nutritional security. Current Science, 109(6), 1171-1176.

Sadeghzadeh, B. (2013). A review of zinc nutrition and plant breeding. Journal of Soil Science and Plant Nutrition, 13(4), 905-927.

Saha, U., Fayiga, A., \& Sonon, L. (2017). Selenium in the soilplant environment: A review. International Journal for Applied Agricultural Sciences, 3(1), 1-8.

Salem, H. M., \& El-Gizawy, N. K. B. (2012). Importance of micronutrients and its application methods for improving maize (Zea mays L.) yield grown in clayey soil. Chemical Analysis, 19, 19

Seadh, S. E., El-Abady, M. I., El-Ghamry, A. M., \& Farouk, S. (2009). Influence of micronutrients foliar application and nitrogen fertilization on wheat yield and quality of grain and seed. Journal of Biological Sciences, 9(8), 851-858.

Shehu, B., Merckx, R., Jibrin, J., \& Rurinda, J. (2018). Quantifying variability in maize yield response to nutrient applications in the northern Nigerian savanna. Agronomy, $8(2), 18$.

Singh, B., Natesan, S. K. A., Singh, B. K., \& Usha, K. (2005). Improving zinc efficiency of cereals under zinc deficiency. Current Science, 88, 36-44.

Söderström, M., Piikki, K., Stenberg, M., Stadig, H., \& Martinsson, J. (2017). Producing nitrogen (N) uptake maps in winter wheat by combining proximal crop measurements with Sentinel-2 and DMC satellite images in a decision support system for farmers. Acta Agriculturae Scandinavica, Section B-Soil \& Plant Science, 67(7), 637-650.

Stein, A. J. (2010). Global impacts of human mineral malnutrition. Plant and Soil, 335(1-2), 133-154.

Toenniessen, G., Adesina, A., \& DeVries, J. (2008). Building an alliance for a green revolution in Africa. Annals of the New York Academy of Sciences, 1136(1), 233-242.

Towett, E. K., Shepherd, K. D., \& Lee Drake, B. (2016). Plant elemental composition and portable Xray fluorescence (pXRF) spectroscopy: Quantification under different analytical parameters. XRay Spectrometry, 45(2), 117-124.

Underwood, E. J. (1977). Heavy metals and selenium in human and animal nutrition. New York: Academic Press.

Underwood, E. J., \& Suttle, N. F. (1999). Selenium-mineral nutrition of Livestock. Midlothian: CAB International.

United Nations, Department of Economic and Social Affairs, Population Division. (2015). World population prospects: The 2015 revision, Key Findings and Advance Tables. Working Paper No. ESA/P/WP.241.

Upadhyay, R. G., \& Singh, A. (2016). Effect of nitrogen and zinc on nodulation, growth and yield of cowpea Vigna unguiculata. Legume Research, 39(1), 149-151.

USEPA. (1980). US Environmental Protection Agency. Ambient water quality criteria for copper and lead. Springfield: National Technical Information Service, 81, 117681.

van Vugt, D. (2018). Participatory approaches to diversification and intensification of crop production on smallholder farms in Malawi. Doctoral dissertation, Wageningen University.

Vanlauwe, B., Descheemaeker, K., Giller, K. E., Huising, J., Merckx, R., Nziguheba, G., et al. (2015). Integrated soil fertility management in sub-Saharan Africa: Unravelling local adaptation. Soil, 1, 491-508. https://doi.org/10.5194/ soil-1-491-2015.

Vera, A., Moreno, J. L., García, C., Morais, D., \& Bastida, F. (2019). Boron in soil: The impacts on the biomass, composition and activity of the soil microbial community. Science of the Total Environment, 685, 564-573.

von Grebmer, K., Saltzman, A., Birol, E., Wiesman, D., Prasai, N., Yin, S., Yohannes, Y., Menon, P., Thompson, J., \& Sonntag, A. (2014). 2014 Global hunger index: The challenge of hidden hunger. Bonn, Washington, D.C., and Dublin: Welthungerhilfe, IFPRI. http://dx.doi.org/10. 2499/9780896299580.

Welch, R. M., \& Graham, R. D. (2002). Breeding crops for enhanced micronutrient content. In J. J. Adu-Gyamfi (Ed.), Food security in nutrient-stressed environments: 
Exploiting plants' genetic capabilities. Developments in plant and soil sciences (Vol. 95). Dordrecht: Springer.

Welch, R. M., \& Graham, R. D. (2012). Perspectives on enhancing the nutritional quality of food crops with trace elements. In T. W. Bruulsema, P. Heffer, R. M. Welch, I. Cakmak, \& K. Moran (Eds.), Fertilizing crops to improve human health: A scientific review first edition, IPNI, Norcross, GA, USA. Paris: IFA.

White, P. J., \& Broadley, M. R. (2009). Biofortification of crops with seven mineral elements often lacking in human diets-iron, zinc, copper, calcium, magnesium, selenium and iodine. New Phytologist, 182(1), 49-84.

Wortmann, C. S., Kaizzi, K. C., Maman, N., Cyamweshi, A., Dicko, M., Garba, M., et al. (2019a). Diagnosis of crop secondary and micro-nutrient deficiencies in sub-Saharan Africa. Nutrient Cycling in Agroecosystems, 113(2), 127-140. https://doi.org/10.1007/s10705-018-09968-7.

Wortmann, C. S., Kaizzi, K. C., Maman, N., Cyamweshi, A., Dicko, M., Garba, M., Milner, M., Senkoro, C., Tarfa, B.,
Tettah, F., Kibunja, C., Munthali, M., Nalivata, P., Nkonde, D., Nabahungu, L., Ouattara, K., Serme, I., Wortmann, C. (2019a). Tropical africa crop nutrient diagnosis data set. https://doi.org/10.5061/dryad.5t065bb/1.

Zhang, Y., Shi, R., Rezaul, K. M., Zhang, F., \& Zou, C. (2010). Iron and zinc concentrations in grain and flour of winter wheat as affected by foliar application. Journal of Agricultural and Food Chemistry, 58(23), 12268-12274.

Zou, C. Q., Zhang, Y. Q., Rashid, A., Ram, H., Savasli, E., Arisoy, R. Z., et al. (2012). Biofortification of wheat with zinc through zinc fertilization in seven countries. Plant and Soil, 361, 119-130. https://doi.org/10.1007/s11104-012/ 369-2.

Publisher's Note Springer Nature remains neutral with regard to jurisdictional claims in published maps and institutional affiliations. 